\title{
L'arquitectura en l'educació obligatòria: mitjà o finalitat
}

\section{Rubèn Pineda*}

Resum

A l'empara de la nova Llei d'Arquitectura -per la qual es referma la necessitat que s'ensenyi en l'educació obligatòria- i en la cruilla de la primavera de renovació pedagògica -que sacseja les finalitats i els mètodes que hegemònicament s'han esdevingut a les aules-, aquest article aborda la disjuntiva que l'arquitectura s'instauri com una finalitat en si mateixa o com un mitjà per tal d'accedir a altres escenaris educatius. A partir d'una revisió de diverses experiències, s'exploren alternatives pel que fa a les finalitats dels coneixements de l'arquitectura, del fet arquitectònic i de la professió d'arquitecte. Així mateix, s'explora la inclusió de l'arquitectura en els currículums com a noves oportunitats per revisar les metodologies educatives i els processos d'ensenyament-aprenentatge.

Paraules clau

Educació, arquitectura, capacitació, interpretació, transformació, dibuix, maqueta, arquiescola

Recepció original: 10 de febrer de 2021

Acceptació: 22 de març de 2021

Publicació: 1 de juny de 2021

\section{Horitzons de canvi}

\section{On ha estat l'arquitectura?}

L'arquitectura no ha disposat abans d'un espai curricular propi en les matèries que conformen els continguts oficials dels ensenyaments obligatoris, ja sigui a Infantil, Primària o Secundària, així com tampoc a Batxillerat.

Les seves aparicions en els continguts d'aprenentatge dels infants i joves han estat dèbils, fragmentades i inconnexes. Podem visualitzar exemples a la Història de l'Art del Batxillerat d'Humanitats i Ciències Socials, en el marc dels estils artístics, sovint des d'una òptica propera a les arts plàstiques i/o a l'escultura. També s'aborden algunes qüestions a l'àrea de Tecnologia de $3 r$ i 4t d'ESO, quan es treballa l'habitatge, en relació a l'energia i el seu consum, les instal.lacions, o en l'estudi dels materials.

El Dibuix Tècnic que es fa al Batxillerat tant a la modalitat de Ciències i Tecnologia com a la d'Arts, disposa d'una certa correlació perquè desenvolupa capacitats i aporta eines i codis necessaris en l'arquitectura i diverses enginyeries, tanmateix el seu plantejament inamovible continua descontextualitzat de la realitat. En el tastet que els alumnes hauran fet prèviament a I'ESO, dins l'assignatura d'Educació Visual i Plàstica, la situació

$\left(^{*}\right) \quad$ Arquitecte per la UPC i doctor en Arts i Educació per la UB. Ha treballat a Primària, ensenyant arquitectura a alumnes de 6 a 12 anys, i a Secundària i Batxillerat, com a professor de Dibuix, Matemàtiques i Tecnologia. La seva tesi doctoral El procés d'adquisició de la noció de VOLUM. Una recerca basada en la pràctica sobre les capacitats espacials i el pensament tridimensional, per al seu desenvolupament a l'Educació Primària (2017) explora el desenvolupament de les capacitats espacials i de com s'adquireix la noció de volum en infants de 67 anys. Ha estat assessor del programa Magnet en aliança amb el Col-legi Oficial d'Arquitectes de Catalunya. Adreça electrònica: rpineda3@xtec.cat 
no és gaire diferent perquè també s'acostuma a seguir la seqüència de classe magistral i làmina per abordar geometries abstractes.

Altres matèries que poden tenir relació amb l'arquitectura són: les Matemàtiques i les seves aportacions a la geometria (amb duplicació o absència de continguts), la Història en les Ciències Socials quan es parla dels assentaments o la Física per l'estabilitat dels components estructurals. Encara que podríem trobar altres connexions, mereix un rol destacat el Dibuix Artístic, habitualment menys associat a l'arquitectura tot i que el dibuix, per a molts, respon a l'acte més genuí i essencial, que canalitza i plasma la creativitat dels arquitectes.

Analitzant les oportunitats de què no ha disposat l'arquitectura dins el sistema educatiu formal, constatem que s'han tractat insuficientment algunes qüestions bàsiques com el valor i la comprensió de l'espai, la llum i la seva qualitat, els usos i el funcionament, la forma i les relacions, i altres que acabaran bastint la riquesa i complexitat que subjau en l'arquitectura, -potser- origen de la seva bellesa i inaprehensibilitat.

Haver prescindit de l'arquitectura, vista la responsabilitat que té com a generadora de l'espai de l'hàbitat i possibilitadora de les activitats humanes, ens duu a concloure que els currículums actuals no són els adients per a formar futurs ciutadans amb capacitat crítica per comprendre, actuar i millorar la nostra acció sobre l'entorn en el que ens desenvolupem (Morales, 1998; Muntañola, 1973).

Sortosament, durant els darrers anys nombrosos col-lectius, associacions i educadors han ofert la seva pràctica i coneixements per tal de fomentar la comprensió i el descobriment de l'arquitectura en la infància i la joventut. A pesar de les dificultats que suposa ocupar els espais marginals que deixava un sistema educatiu sovint rígid, s'han realitzat activitats molt interessants i reconegudes, ja sigui des de projectes de llarga durada, tallers puntuals realitzats als centres o activitats extraescolars.

Posant en valor els espais intermedis del sistema educatiu com a aquells escenaris frontissa on el frec i una major permissivitat permet que neixin iniciatives i s'hi allotgin transformacions (Cobo i Moravec, 2011), nombroses experiències han posat el focus en les qüestions conceptuals i topològiques (Muntañola, 1984) de l'arquitectura, sovint guiades pel joc com a factor d'èxit.

Tanmateix, en relació a la manca de continuïtat i temps disponible, sovint les activitats han estat meticulosament però excessivament programades, amb dissenys ficticis, previsibles i resultats artificials. El que hauran estat activitats vistoses, podrien haver resultat poc transformadores. Aquí radiquen els seus dubtes.

\section{L'oportunitat en forma de llei en un context en transició}

Amb l'aprovació al Parlament de Catalunya de la Llei de l'Arquitectura (Gencat, 12/2017) impulsada pel COAC (Col-legi Oficial d'Arquitectes de Catalunya), s'estableixen mesures per al seu foment com a bé d'interès públic, individual i també col·lectiu, per mitjà de la inclusió de continguts formatius en l'ensenyament obligatori i universitari.

A la llei es promou «l'educació sobre l'arquitectura, el patrimoni construït, i llur incidència sobre les condicions i la qualitat de vida, i també la importància del seu manteniment en la fase d'explotació» (art. 3d), mitjançant «la difusió, la sensibilització i el coneixement de l'arquitectura i el patrimoni construït» (art. 5a). 
En la mateixa línia, a l'article $6 \mathrm{~b}$ es proposa «promoure l'ensenyament de l'arquitectura, del patrimoni construït en el seu vessant pluridisciplinari i dels aspectes que tenen incidència en la qualitat de vida de les persones».

El text enceta un escenari en el qual, inexorablement, l'arquitectura hi farà presència i deixarà d'estar isolada en els currículums educatius (Romañá, 2015), com ha vingut succeint i es comentava prèviament, al mateix temps que es van resolent alguns dels dubtes de com, qui i quan es concretarà aquest desplegament.

El COAC, mitjançant l'aplicació del seu recent programa educatiu, Arquiescola ${ }^{1}$, ofereix recursos i resulta un excel-lent punt de partida per emmarcar conceptualment les noves experiències relacionades amb l'arquitectura. S'aprofita l'avinentesa que el COAC esdevé partner de referència i innovació de diversos centres públics dins el programa Magnet $^{2}$, el qual projecta una transformació profunda d'aquests centres a quatre anys vista, establint-hi l'arquitectura com a eix educatiu vertebrador, amb l'objectiu final de lluitar contra la segregació escolar i reequilibrar la composició de l'alumnat.

Algunes previsions pel que fa al professorat, proposen incloure els fonaments de l'educació arquitectònica en les seves etapes de formació inicial i continuada (Pineda et al., 2018), per tal de transmetre la transcendència de l'arquitectura en els processos educatius i la seva relació amb la innovació (Schabmann et al., 2016).

Pel que fa a l'alumnat, aquest article fa propis i sintetitza alguns dels objectius proposats per Laaksonen i Räsänen (2006): l'educació arquitectònica com a font d'aprenentatge, reforça en l'alumne la capacitat de veure, avaluar i analitzar críticament el medi construït, i desenvoluparà el seu pensament crític i creatiu. A més, en un context democràtic, pot col-laborar en desenvolupar les habilitats necessàries i potenciar el desig de participar en processos de canvi per millorar l'entorn construït en relació al futur del medi ambient.

En el marc legislatiu educatiu que fa referència a les Competències $\mathrm{Clau}^{3}$ (Gencat, 143/2007, Annex 1) hi trobem certes al-lusions a les finalitats prèviament citades. La competència en el coneixement i la interacció amb el món físic (7) consisteix en la:

Mobilització de sabers que han de permetre a l'alumnat comprendre les relacions que s'estableixen entre les societats i el seu entorn i fer un ús responsable dels recursos naturals, tenir cura del medi ambient, fer un consum racional i responsable i protegir la salut individual i col-lectiva com a elements clau de la qualitat de vida de les persones (Gencat, 2008, p. 8).

(1) Arquiescola, el programa educatiu del COAC, ofereix recursos als docents per treballar transversalment l'arquitectura des de 3 eixos: cos, hàbitat i territori, amb conceptes com la perspectiva de gènere, la diversitat funcional i cultural, la sostenibilitat i la identitat.

(2) Magnet: Aliances per a l'èxit educatiu és un programa d'innovació per a l'equitat educativa i la lluita contra la segregació escolar, impulsat per la Fundació Jaume Bofill, en colllaboració amb el Departament d'Ensenyament, I'Institut de Ciències de l'Educació (ICE) de la UAB i la Diputació de Barcelona, que proposa acompanyar els centres educatius per teixir una aliança amb una institució de prestigi. El marc d'aquesta aliança impulsa el centre i la institució a desenvolupar un projecte educatiu innovador i de qualitat, un projecte atractiu i magnètic que es converteixi en un projecte de referència en el seu territori, tant per les famílies com per la comunitat educativa.

(3) Originalment anomenades Competències Bàsiques, actualment ens hi referim com a Competències Clau per diferenciar-les de les CBs de cada àmbit i matèria. 
Mentre que la segona de les competències específiques centrades a conviure i habitar el món, I'anomenada social i ciutadana (8) s'explica com la:

Capacitat per comprendre la realitat social en què es viu, afrontar la convivència i els conflictes emprant el judici ètic que es basa en els valors i pràctiques democràtiques i exercir la ciutadania, actuant amb criteri propi, contribuint a la construcció de la pau i la democràcia i mantenint una actitud constructiva, solidària i responsable davant el compliment dels drets i obligacions cívics (Gencat, 2008, p. 8).

L'establiment del currículum competencial en les diverses etapes obligatòries d'acord amb els quatre Pilars de l'Aprenentatge establerts per la UNESCO a l'informe Delors (1996), els aprendre a: conèixer, fer, ser i conviure és relativament recent ${ }^{4}$. Prèviament a l'era competencial, en els centres educatius primaven els continguts del conèixer, conformant una base essencialment memorística.

Actualment ens trobem en una nova fase en la qual ho estem focalitzant al fer, i així li estem donant més sentit a les competències en tant que impliquen acció de coneixements i habilitats per a la seva aplicabilitat a contextos diversos i situacions complexes. En canvi, és habitual la desatenció als dos darrers pilars de l'aprenentatge, el ser i el conviure plegats.

Posar el focus en una educació global on també es contemplin aquestes altres formes d'aprenentatge ens apropa a l'objectiu educatiu d'ajudar els ciutadans a ser crítics i apoderats, en marcs de convivència, tolerància i pau. Aquesta és la tasca primordial de l'escola: collaborar en la formació de persones lliures i capacitades, felices, amb valors i integrades en la societat.

Dins la primavera de renovació pedagògica actual (Carbonell, 2016), destaca la Xarxa de Competències Bàsiques per la seva trajectòria en compartir experiències i materials per un canvi de paradigma cap a una educació competencial, en la qual encara hi ha marges de reflexió, desplegament i millora.

Recentment, el Departament d'Educació s'ha compromès a estendre i consolidar el programa Escola Nova 21 a tots els centres públics i concertats de Catalunya, model que planteja revisar radicalment quatre eixos interdependents: el propòsit educatiu, les pràctiques d'aprenentatge, l'avaluació i l'organització.

(4) Aprendre a Conèixer: Desenvolupar les eines cognitives necessàries per a comprendre millor el món i les seves complexitats, i per proporcionar una base apropiada i adequada per a l'aprenentatge futur. Aprendre a Fer: Desenvolupar les habilitats per participar efectivament en la societat del coneixement, saber afrontar situacions complexes i treballar en equip. Aprendre a Ser: Desenvolupar capacitats auto-analítiques i socials per assumir les responsabilitats de la llibertat, i desplegar els potencials psico-social, afectiu i físic. Aprendre a Conviure: Desenvolupar les actituds i valors per al desenvolupament sostenible i la pau, perquè les persones i les societats puguin conviure harmònicament. 
En el marc d'escola avançada, el propòsit i finalitat educativa s'alinea amb els quatre pilars de l'educació abans esmentats i es recolza en els disset Objectius de Desenvolupament Sostenible ${ }^{5}$ (UNESCO, 2017); les pràctiques d'aprenentatge milloren la seva efectivitat basant-se en les evidències dels set Principis d'Aprenentatge ${ }^{6}(O E C D, 2010)$; l'avaluació evoluciona a una eina per millorar l'aprenentatge i l'ensenyament cognitiu, físic, emocional i social; l'organització del centre es revisa, desencotilla i transforma per estar al servei dels eixos anteriors.

Com es pot observar, assistim a nous escenaris en els que l'arquitectura i el patrimoni construït s'inseriran en les etapes educatives per tal de col-laborar en la formació dels infants i joves com a ciutadans actius, capaços, crítics i compromesos, en línia amb el desenvolupament de les Competències Clau, els Pilars de l'Educació i els ODS per al 2030, però com plantejar aquesta inserció en l'actual model educatiu?

Agrupar la fragmentació curricular precedent, renovar-la i actualitzar-la per tal de crear una nova matèria que es digui arquitectura o formació arquitectònica semblaria subestimar el seu gran potencial i, en efecte, allunyar-nos de les onades de renovació pedagògica per les quals cal descentralitzar els continguts.

En contraposició, l'arquitectura entesa com a font d'aprenentatge competencial és sinònim de treball col-laboratiu i relació social, i permet implicar activament l'alumnat en els processos d'aprenentatge, a través de les emocions com a part integral.

L'arquitectura disposa de possibilitats enormes per bastir connexions horitzontals entre àrees de coneixement i activitats, promovent la translació de les estructures de coneixement a noves situacions, i entenent la seva magnitud més enllà dels continguts.

\section{Vector transversal}

\section{Les finalitats educatives de l'arquitectura}

En els propers paràgrafs, explorarem plantejar l'arquitectura no com a contingut en si mateixa sinó com a mitjà per embastar altres continguts, a fi i efecte d'aconseguir transformacions profundes i permanents.

Així, en addició a altres experiències que plantegen un primer contacte amb els conceptes principals de l'arquitectura, es suggereix orquestrar l'arquitectura transversalment, a la qual s'hi vinclin la resta de matèries, fomentant connectivitats que promoguin contextualització i significativitat entre continguts aparentment dispars.

Cal no ensenyar arquitectura sinó descobrir l'arquitectura present a tot arreu i implementar en els alumnes els processos de pensar, actuar i comunicar com faria un arquitecte, ja que «l'aprenentatge està vinculat a processos de presa de consciència. Aprenem

(5) Els disset Objectius de Desenvolupament Sostenible (ODS) per al 2030 són: fi de la pobresa, fam zero, salut i benestar, educació de qualitat, igualtat de gènere, aigua neta i sanejament, energia neta i assequible, treball digne i creixement econòmic, indústria, innovació i estructures, reducció de les desigualtats, ciutats i comunitats sostenibles, consum i producció responsables, acció climàtica, vida submarina, vida terrestre, pau, justícia i institucions sòlides, i aliança pels objectius.

(6) L'alumnat ha de ser el centre de l'aprenentatge, l'aprenentatge és un procés de naturalesa social, les emocions són part integral de l'aprenentatge, l'aprenentatge ha de tenir en compte les diferències individuals, l'esforç és clau per a l'aprenentatge, l'avaluació continuada afavoreix l'aprenentatge i, aprendre consisteix a construir connexions horitzontals entre àrees de coneixement i matèries. 
fent, reflexionant sobre el que fem i revisant el que sabem fer. Sabem que quan hi ha una intenció comunicativa aquests processos creixen exponencialment» (De la Cerda, 2016, p. 54). Aquest és el potencial i aquest és el repte transformador.

Al cos docent, es proposa fer una crida als arquitectes que ja són professors i mestres, sovint però no exclusivament des de disciplines afins com la Tecnologia, les Matemàtiques o el Dibuix. Per tal de garantir la sostenibilitat en la inserció de l'arquitectura en I'ADN educatiu, cal implicar també docents no arquitectes gràcies a formació específica en cursos de capacitació. I possibilitar també que arquitectes professionals no docents actualitzin les mirades i participin en projectes i processos en els propis centres.

Metodològicament, es proposa prioritzar els processos d'indagació i els recorreguts oberts, democràtics i participatius, per damunt dels resultats, mitjançant metodologies afins al treball per projectes (Hernández, 2000; Hernández-Hernández et al., 2016), a l'aprenentatge basat en problemes (Branda, 2009) i a l'Aprenentatge Servei ${ }^{7}$ (Martín, 2011; Palos, 2011) ${ }^{8}$.

En la següent imatge (Figura 1) i en els propers apartats es mostraran diverses experiències educatives que exemplifiquen com vertebrar un projecte educatiu per mitjà de l'arquitectura, en funció de tres finalitats relacionades:

Figura 1: Esquema gràfic dels tres objectius / finalitats

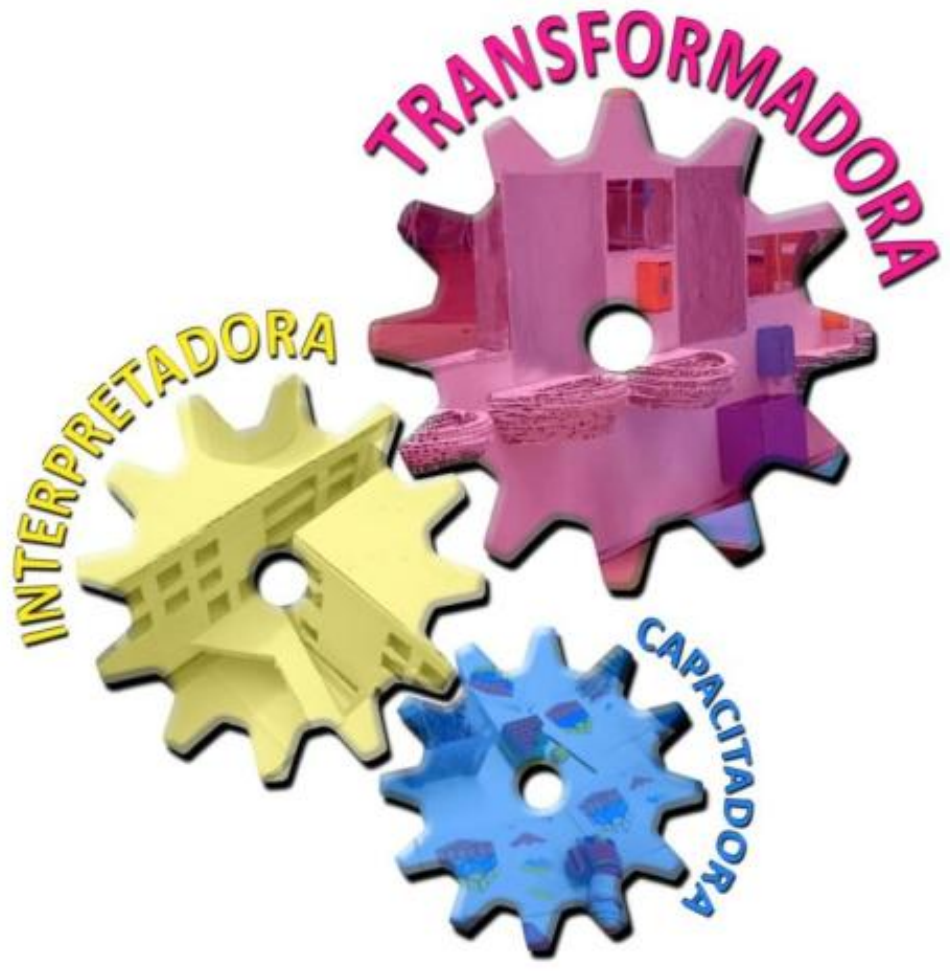

Font: Elaboració pròpia.

(7) L'Aprenentatge Servei és un servei comunitari que s'integra amb els objectius d'aprenentatge del currículum acadèmic, en el qual s'ofereixen als estudiants experiències d'aprenentatge en context i basades en situacions autèntiques de la vida real de les seves comunitats, les quals al seu torn també s'impliquen en la millora i el compromís educatiu dels seus joves.

(8) Els articles de Xus Martín i José Palos, inclosos en el monogràfic número 41 de Temps d'Educació dedicat a l'Aprenenatge Servei (2011), posen de relleu l'estreta relació històrica entre els treballs per projectes amb vocació social i de servei, i també la versatilitat de l'ApS per desenvolupar aprenentatges competencials. 
1. Capacitadora: activitats que fonamentalment es proposen el desenvolupament d'habilitats i capacitats per tal de transcendir els límits intel-lectuals dels alumnes.

2. Interpretadora: amb finalitat analítica i de comprensió de l'entorn i del patrimoni construït a partir de la descomposició conceptual dels seus paràmetres i elements constitutius.

3. Transformadora: quan es mobilitza la crítica constructiva per tal de qüestionar, evolucionar, tergiversar i replantejar un disseny arquitectònic, urbanístic o de producte.

L'arquitectura com a vector transversal ofereix els tres tipus de finalitats de manera complementària en funció de les edats i el context, entenent-les dualment com a categories aïllades o també presents en diversa variabilitat dins una mateixa activitat.

La necessitat d'incidir en les tres categories a l'ESO és cabdal pel perill de la seva adquisició descompensada: la crítica sense anàlisi és buida, esdevé opinió arbitrària; una anàlisi sense capacitació ni base de coneixement resulta superficial; una capacitació sense eines de dissecció o anàlisi, ni una finalitat crítica en un horitzó de millora seria la pitjor de les combinacions, generant ciutadans adaptats i dòcils.

\section{L'arquitectura com a instrument per a la capacitació}

L'origen de la proposta Dibuixos Construïts se situa en un exercici previ en el qual es va convidar l'alumnat de $1 \mathrm{r}$ i $2 \mathrm{n}$ de Primària a realitzar, pautadament, un dibuix senzill seguint les lleis de la perspectiva amb línia d'horitzó (LH) i dos punts de fuga. L'experiència va posar de manifest que l'alumnat podia seguir les instruccions teòriques prèvies, estava motivat per l'aprenentatge i orgullós dels resultats.

Tot i la percepció que hi havia hagut progressos en el desenvolupament de la intel.ligència múltiple Espacial (Gardner, 1983, 2012, 2013) i en la construcció de la noció de volum, es va plantejar evolucionar la metodologia cap a espais d'experimentació que permetessin una aproximació més crítica i vivencial per l'adquisició dels conceptes de la línia d'horitzó, del volum i de la perspectiva (Pineda, 2017), amb quatre fases:

1. En un full es marca una línia horitzontal per representar l'horitzó i es pinten el cel i el terra, que seran el paisatge de fons.

2. En un altre espai gràfic es dibuixen figures amb mides diverses com persones, arbres, animals, cases o altres elegides lliurement, flotant a l'espai en blanc del paper i sense superposicions, que també es pintaran i retallaran.

3. Finalment cal crear, amb l'ajuda dels companys, diverses possibilitats de col·locació de les figures dins l'escenari generat, simulant perspectiva i profunditat.

4. Es documenten els diferents assajos per tal de visualitzar posteriorment les propostes obtingudes amb tot el grup, i així sintetitzar aprenentatges.

En comptes de partir del full en blanc, l'estratègia és l'oferiment d'un espai gran i profund en el qual poder assajar «a veure com es veu si ho pujo més amunt o si ho poso més avall» (Figura 2). Es possibiliten situacions que no es produeixen en el dibuix quotidià, el qual «el fas com saps, o com et surt». És dibuix per etapes, dibuix construït. 
Figura 2: Seqüència de proves de distribució de les figures en l'escenari per tal de veure'n els efectes visuals

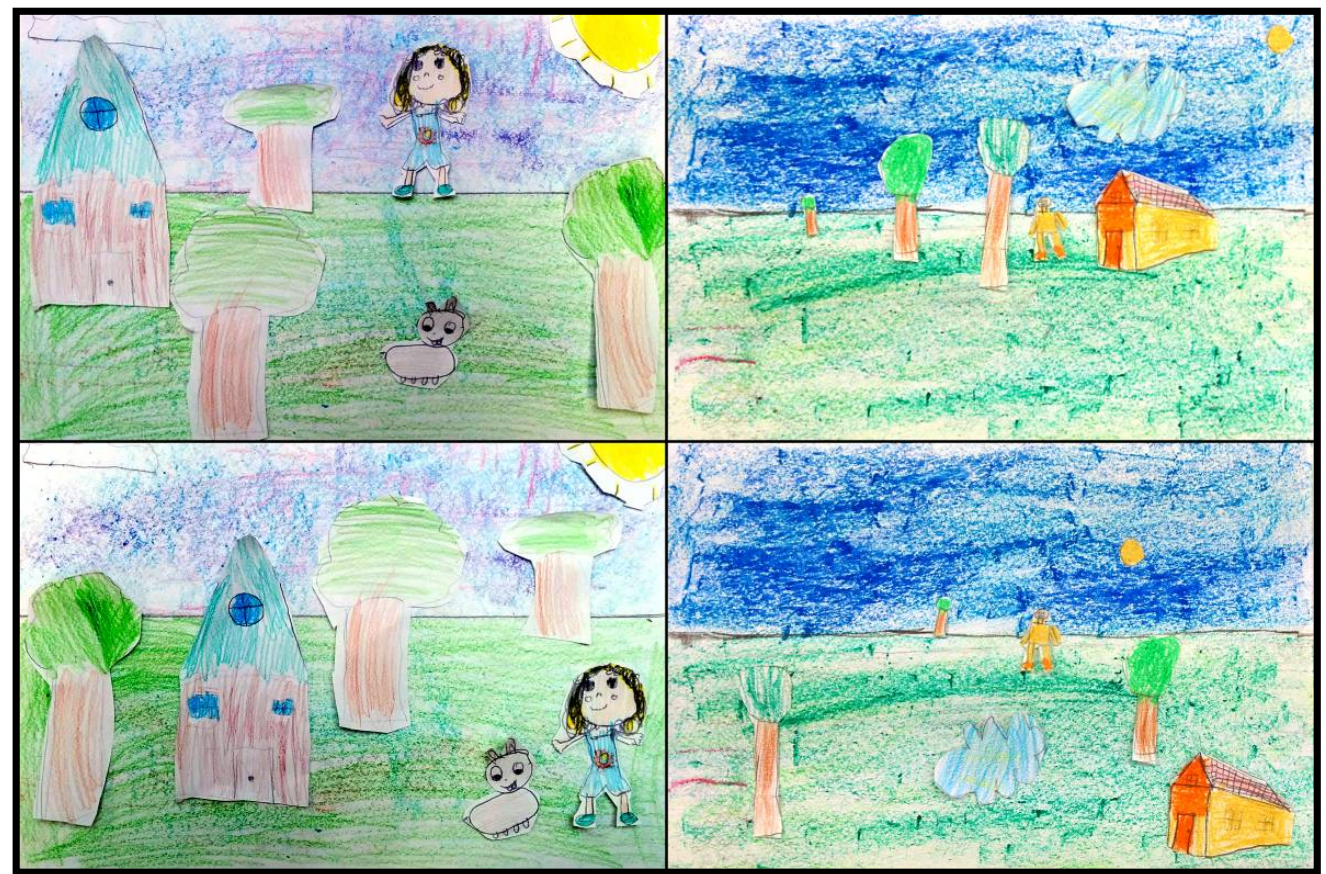

Font: Elaboració pròpia

En les reflexions de grup al voltant de la fenomenologia de com percebem la perspectiva i la profunditat, la tendència observada és que l'alumnat té claríssim que alguna cosa o objecte més gran és més propera i viceversa. Succeeix també que si situen aquests objectes grans en un dibuix, els acostumen a posar a la part inferior i els petits a la part superior, quan en una perspectiva cònica seria més pertinent situar els objectes petits $i$ llunyans més aviat al centre del dibuix. En canvi, I'alumnat amb baixa maduració espacial, situa els objectes al marge del paper o bé damunt la LH.

Desxifrar l'aprenentatge del volum a través de la LH esdevé un punt de partida que marca la diferència entre un dibuix amb profunditat $i$ un que no. Encara que Lowenfeld (1961) consideri l'adquisició de la línia d'horitzó a l'etapa Pseudo-Realística dels 11-13 anys, s'aporten resultats que conviden a plantejar-ho a alumnat força més jove.

Aquesta metodologia dinàmica d'assaig i error es planteja com alternativa per al desenvolupament intuïtiu de les lleis de la perspectiva. L'error sovint esdevé penalitzat en el nostre sistema educatiu i això genera alumnat amb por al fracàs, mentre que el docent té el deure d'exposar l'error en positiu, perquè pugui ser percebut com una oportunitat d'aprenentatge.

L'activitat Construccions amb Lego que s'explica parteix de dibuixos en 3D realitzats per alumnat de $3 \mathrm{r}$ i $4 \mathrm{t}$ de Primària, gràcies a una fitxa especialment dissenyada per dibuixar figures cúbiques en el sistema de representació isomètric.

En aquest treball combinat es van poder generar 100 fitxes plastificades i classificades en 6 nivells de complexitat creixent. Les figures més grans possibles són cubs de 3 pisos 
d'altura i 9 peces per planta, amb un total de 27 peces, i a la dreta de la fitxa hi ha la representació de les 3 plantes i la relació d'espais buits i plens (Figura 3).

Figura 3: Representació axonomètrica i les respectives plantes de diverses figures de dificultat diversa construïdes prèviament amb peces cúbiques

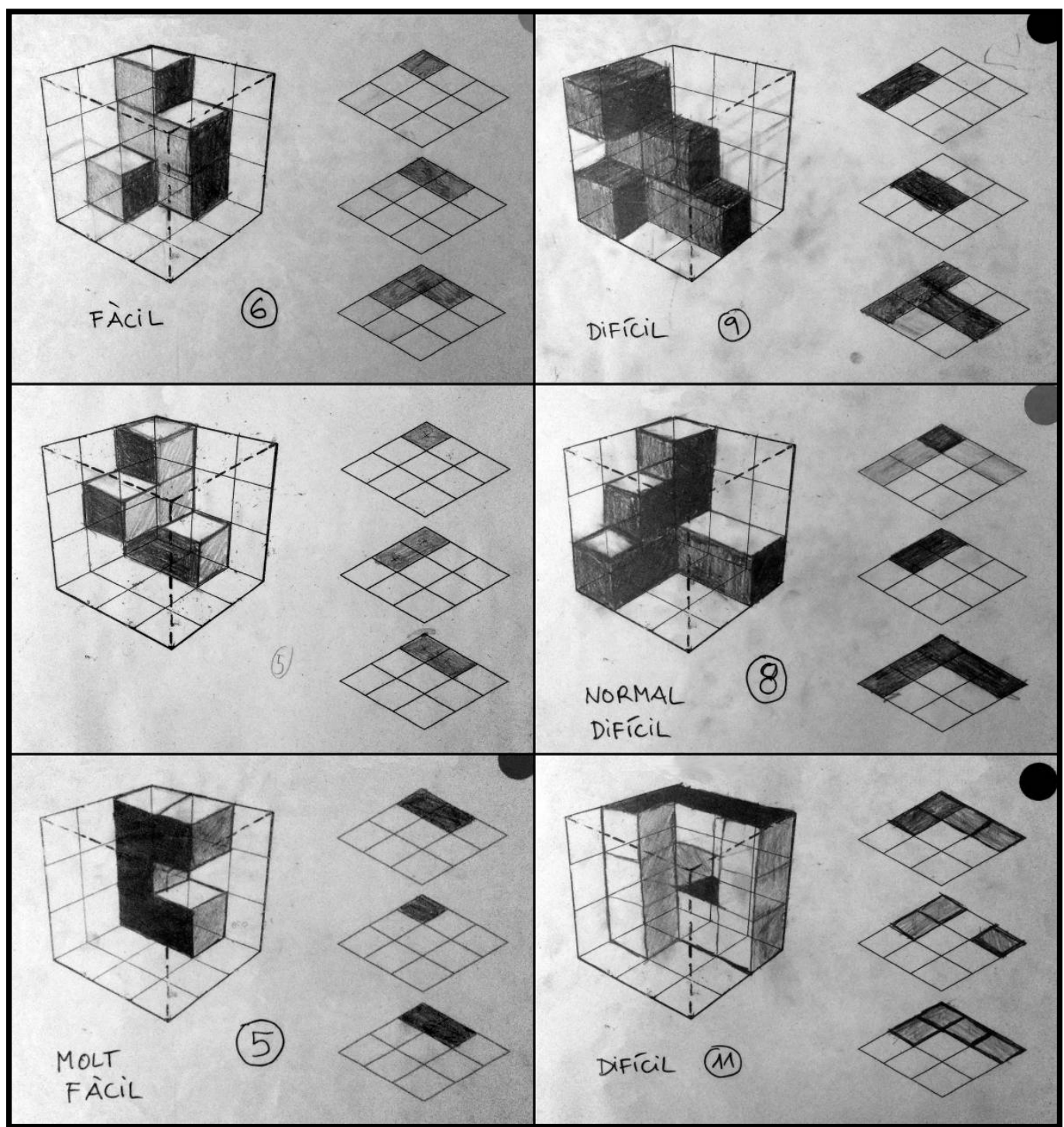

Font: Elaboració pròpia

El treball que realitza l'alumnat de $1 \mathrm{r}$ i 2 n consisteix en muntar les figures que hi ha dibuixades a les fitxes. Primer cal seleccionar les peces necessàries, fixant-se en el nombre que hi ha a la fitxa. Així es genera un element de control autogestionat perquè no podrà sobrar ni mancar cap peça. Després aniran construint la figura, comparant la visió que tenen de la representació amb la visió de la construcció que van fent.

L'ús de les plantes annexes s'ha observat favorable per impulsar certs alumnes a construir la figura tridimensionalment amb més autonomia. No obstant això, la finalitat principal no radica en la culturització visual, sinó en l'establiment de la correlació mental entre visualitzacions bidimensionals analítiques i representacions tridimensionals sintètiques.

Donada la disparitat inicial de nivells d'execució observats en els nens i nenes de $1 \mathrm{r}$ i $2 \mathrm{n}$, el fet de disposar de tantes fitxes de cada nivell ha fomentat l'aprenentatge autònom de l'alumnat, i així respectar els diversos ritmes d'aprenentatge amb reptes assequibles. 
Superposadament, el treball col-laboratiu ha permès trobar una fitxa adaptada a la Zona de Desenvolupament Propera (Vygotsky, 1996) de l'alumne, convertint l'assoliment d'aquestes primerenques construccions dirigides, amb l'ajuda dels companys/es, en experiències sempre positives.

\section{L'arquitectura com a element d'interpretació}

El projecte que s'exposa ha consistit en la realització de la maqueta de l'església romànica de Sant Climent de Taüll a gran escala per part de grups heterogenis i multinivell de $3 \mathrm{r}$ i $4 \mathrm{t}$ de Primària.

Aquesta maqueta a E:1/10 (10 vegades més petita que la realitat) i utilitzant només cartró com a material de construcció, volia ser una oportunitat per parlar de física intuïtiva, de l'Edat Mitjana o de l'art Romànic. També suposava un test per veure com nens i nenes de 8-9 anys resolien el repte de construir a escala, amb les dificultats abstractives que representa.

El context respon a una aposta del centre per fomentar situacions d'aprenentatges per projectes i potenciant els metaaprenentatges ${ }^{9}$ a través de la col.laboració entre iguals, en la que diversos grups consecutius cooperen i reprenen la feina dels grups precedents.

L'arquitectura com a vertebradora d'aprenentatges transversals i continguts multidisciplinaris ha permès una potenciació de les connexions horitzontals en les competències comunicativa lingüística i audiovisual, artística i cultural, i matemàtica:

a) Durant els debats i les explicacions s'ha fomentat l'ús de la llengua catalana en la vessant cientificotècnica: matemàtica, gràfica, artística, compositiva o constructiva.

b) S'ha aprofundit en el coneixement del context històric, social i cultural de l'època medieval a Catalunya, des del llegat i la transcendència artística d'una peça arquitectònica clau del romànic català.

c) Millorant la comprensió i significació gràfica i plàstica dels conceptes matemàtics (angles, canvis d'escala, divisions, decimals), procediments (la seva aplicació pertinent) i actituds (imaginativa, lògica, deductiva) necessaris per avançar, els quals han aparegut des de l'experimentació i la descoberta.

La metodologia de resolució ha seguit l'estructura de l'Aprenentatge Basat en Problemes en el que cal plantejar l'objectiu, per després pensar i esbrinar com resoldre el problema:

1. Debat i consens per tal d'acordar -entre altres opcions com castells i edificis civilsrealitzar una maqueta de Sant Climent de Taüll.

2. Per cercar informació, les famílies van ajudar a destriar la informació històrica i cultural (edifici de caràcter religiós amb components defensius d'uns 1000 anys d'antiguitat, coneixements constructius de l'Edat Mitjana, etc.), les imatges de la composició formal exterior, i els frescs interiors del pantocràtor de Taüll ubicat al MNAC.

(9) Un metaaprenentatge consisteix en prendre consciència del propi procés d'aprenentatge a través de la reflexió de com s'aprèn, la qual sovint millora mentre s'ensenya a altres companys. 
3. En la planificació del treball vam calcular l'escala òptima de l'edifici (1/10), decidir que el material constructiu seria cartró reciclat, i que la volumetria s'havia de generar des de la interpretació dels tres plànols principals (planta, alçat i secció) a escala 1/100 disponibles (Figura 4).

\section{Figura 4: Interiors, exteriors i elements constitutius de la maqueta de cartró} a E:1/10 de Sant Climent de Taüll

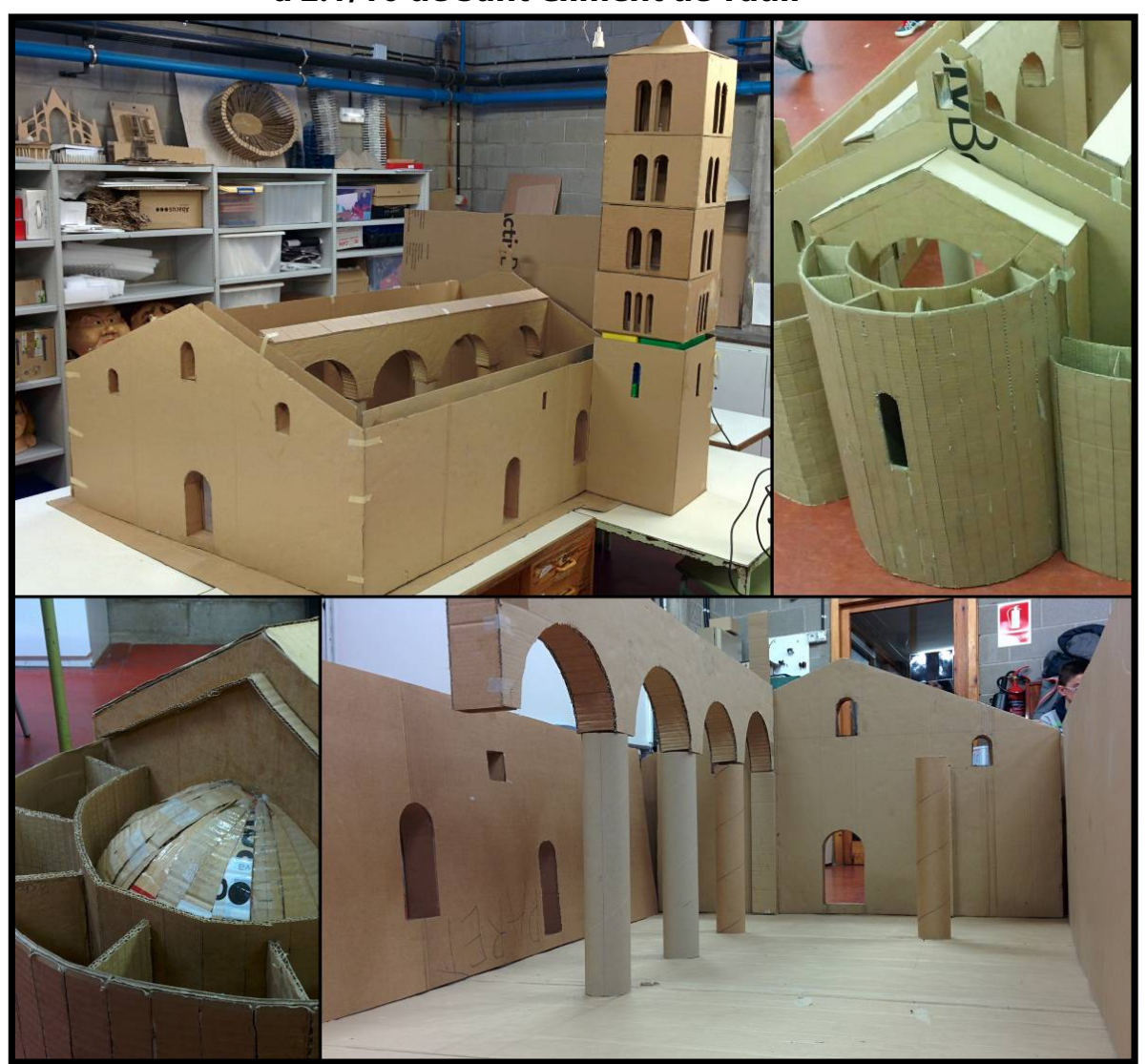

Font: Elaboració pròpia

4. L'edifici es va descomposar en parts (torre, murs, terra, absis, arcs interiors) perquè cada equip de treball configurat de 2-3-4-5 alumnes avancés cooperativament en la descoberta i realització de la peça corresponent.

5. Després de localitzar les peces als plànols i passar les seves mides a l'escala 1/10, s'han dibuixat al material tenint molta cura dels angles rectes, els decimals o les triangulacions. Cada peça és una oportunitat per experimentar la geometria i les matemàtiques.

6. El tallat s'ha realitzat amb cúters, regle metàl-lic i mesures de seguretat. Per enganxar amb pega líquida i pinzell ha calgut pensar en quines parts coincideixen i generar peces de separació i reforç per donar solidesa i estabilitat a les parts interiors i exteriors dels murs.

El Centre Romànic de la Vall de Boí va mostrar interès en exposar la maqueta resultant i en associar-hi una visita cultural amb els alumnes participants, tot i que al final l'exhibició del treball i els aprenentatges es va limitar a les famílies del centre educatiu.

L'activitat Dibuix en Perspectiva realitzada per alumnat de $3 r$ a 6è de Primària ha consistit en dibuixar alguns interiors i exteriors de l'escola per tal de treballar la profunditat dels espais i la perspectiva. 
Aquestes sessions de dibuix amb perspectiva i 1 o 2 punts de fuga, s'han combinat amb altres més analítiques on es desgranava l'espai per tal de poder-lo reproduir amb cert control i garanties (Figura 5).

Figura 5: Dibuixos dels alumnes, anàlisi gràfica d'un espai en perspectiva i alumnes dibuixant al pati

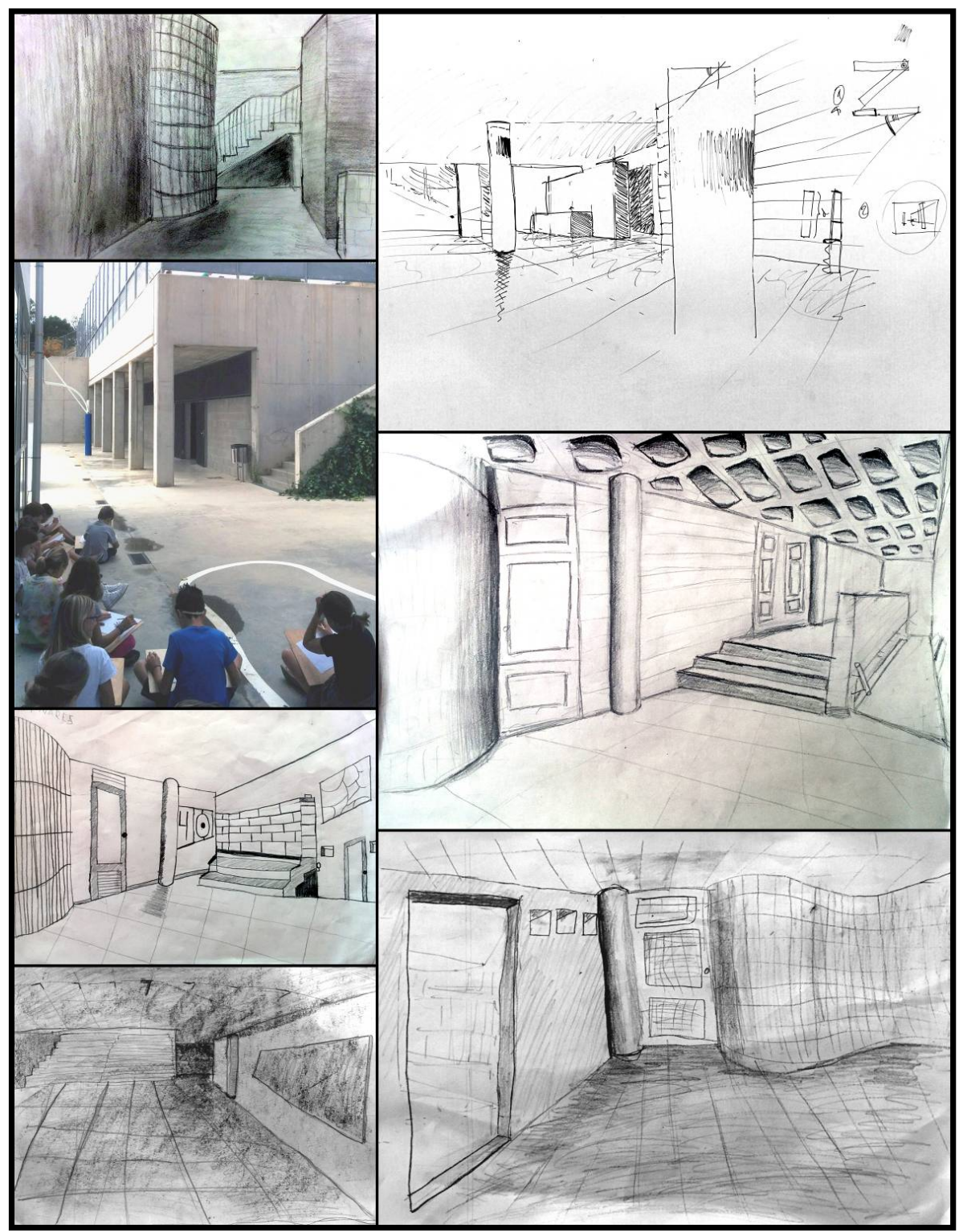

Font: Elaboració pròpia

El focus d'interès pedagògic ha estat capacitar l'alumnat per tal que puguin progressar en la seva destresa representativa i anàlisi de l'espai per damunt de l'excelllència en els resultats figuratius.

En l'activitat hi han abundat els espais de reflexió i així és com hem codissenyat alguns estris de dibuix que ens han permès enquadrar la composició, compartit «trucs» d'ombrejat i inspirar-nos en la resiliència amb el vídeo Austin's Butterfly ${ }^{10}$ (Berger, 2011).

(10) La papallona d'Austin és un vídeo en el que s'explica la història d'un nen que dibuixa una papallona copiada d'una fotografia a través d'una seqüència d'esbossos, cada vegada més fidedignes amb l'original, amb l'ajuda de la crítica constructiva dels seus companys. 
Més enllà de l'interès de l'alumnat per aprendre a dibuixar millor i el plaer d'adonarse'n que són capaços de realitzar, amb una certa pràctica i entrenament, dibuixos d'acurada representativitat, altres motius pedagògics que també s'han debatut han estat:

1. La superació del concepte romàntic d'artista-geni, pel qual es neix amb un do que marca la diferència i que explica perquè alguns nens o nenes destaquen per damunt d'uns altres.

2. La necessitat d'ensenyar a dibuixar amb noves dinàmiques que es desmarquen de la tradició plenament present a les aules, per la qual ni calia ni era aconsellable ensenyar a dibuixar.

3. Evitar l'abandonament del dibuix que es produeix cap als 12 anys mitjançant la racionalització de les causes: frustració paralitzant per un excés d'autoexigència amb el propi dibuix quan aquest s'assembla poc a l'original -segons la percepció del dibuixant.

Amb l'afany de superar la crítica bo/dolent i poder precisar en què ha funcionat millor, hem debatut en com s'ha de valorar un dibuix i quina pot ser l'escala i el sistema. Hem desenvolupat la rúbrica d'autoavaluació per dibuixos en perspectiva amb la idea que l'alumne/a pugui avaluar el seu dibuix per si sol des de paràmetres estables i que concorden amb les seves creences.

Els ítems acordats han resultat: encaix, proporció, perspectiva, ombres més textures i, finalment, realisme, en una escala de l'1 al 4. L'avaluació es posa al servei de l'aprenentatge, esdevé formadora, quan permet descobrir-li a l'alumne/a en què pot millorar i, sobretot, li posa a l'abast la resposta i les eines de com fer-ho.

\section{L'arquitectura amb finalitats transformatives}

El projecte d'entorn Salvem Can Valent, que es va desenvolupar el curs 2018-19, té com a finalitat que no desaparegui la masia de Can Valent, una peça històrica -en estat d'abandonament- ubicada al barri de Porta (Nou Barris) de Barcelona. Es tracta d'una urgència cultural del barri que els alumnes s'han fet seva amb la idea que es converteixi en un nou equipament (Figura 6).

Metodològicament és un Treball per Projectes on compartim finalitat en un procés incert que anem recorrent al voltant del qual construïm aprenentatges del conèixer, fer, ser i conviure. S'ha situat l'alumnat de 4t d'ESO participant al centre de l'aprenentatge amb l'objectiu de desenvolupar el seu pensament crític, la implicació cívica ciutadana i l'emprenedoria personal en accions socials (Morales, 1998). 
Figura 6: Estat ruïnós de la masia de Can Valent, detalls de la superposició de textures i materials, i model 3D realitzat pels alumnes

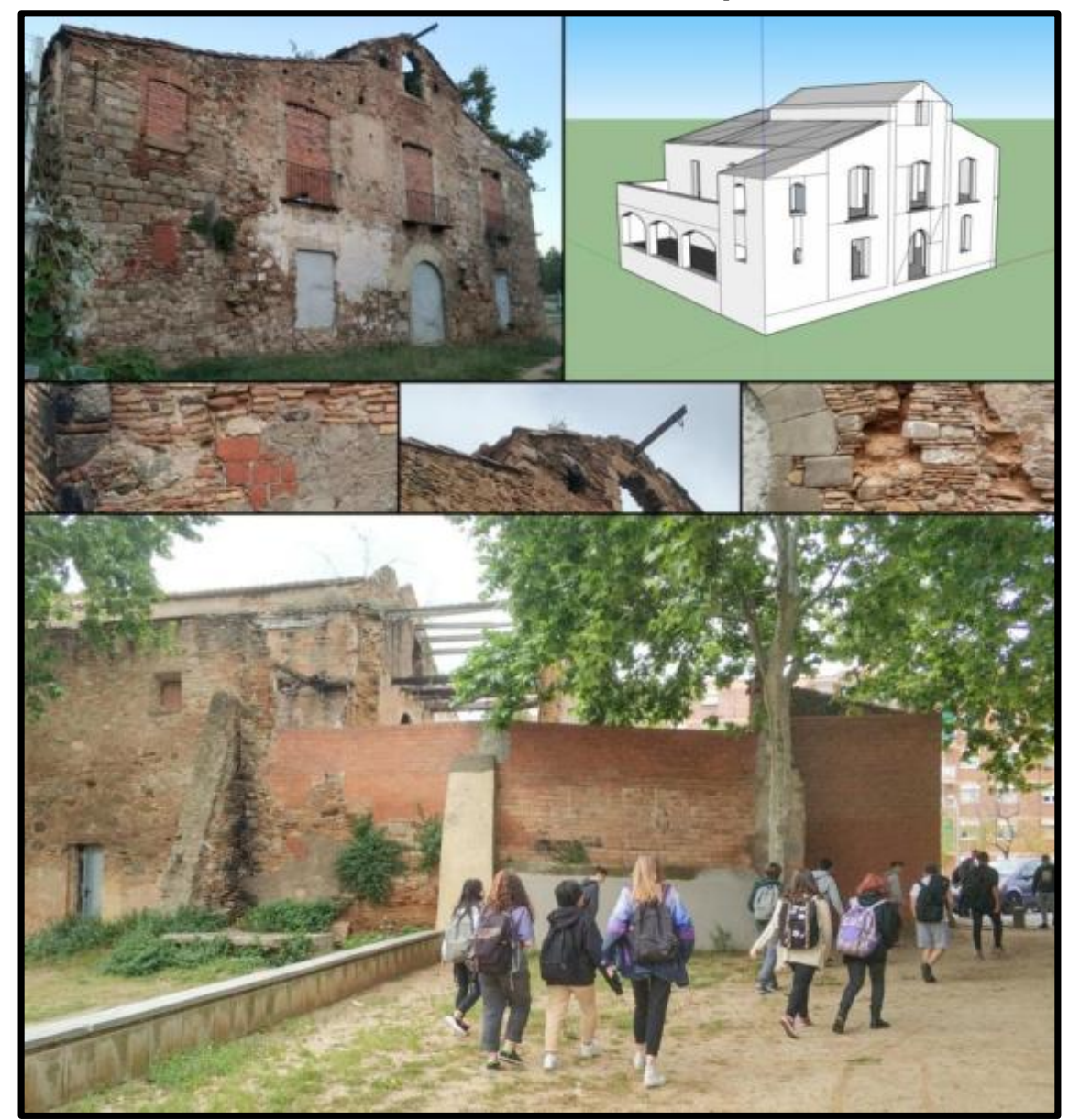

Font: Elaboració pròpia

L'estratègia adoptada és involucrar el màxim d'agents i entitats de l'entorn en l'objectiu educatiu, fet que ens situa en un marc d'Aprenentatge Servei pel qual l'equip del projecte es pot explicar a través de corones:

En la primera hi trobem els nois i noies que desenvolupen el projecte i el docent en les funcions de coordinació i guia.

En la segona hi ha entitats de l'entorn i agents educatius que amb gran entusiasme ens estan donant un cop de mà valuosíssim:

- L'associació de veïns i veïnes (AVV Porta) que connecta amb les reivindicacions veïnals i que són el destinatari del nostre «servei».

- El CRP de Nou Barris que ajuda a co-dirigir el projecte.

- L'Ateneu de Fabricació del Parc Tecnològic de Nou Barris on imprimirem en 3D.

- L'Arxiu Municipal de Nou Barris per documentació històrica.

- El Grup d'Història de Nou Barris per interpretar la història.

- Horta Valenta, Assemblea d'aturats/des de Nou Barris, Porta'm a l'Hort,...

En la tercera està plantejat que s'involucri l'AFA de l'institut, els professors/es, la resta de l'alumnat, el Claustre, el Consell Escolar i que englobi el teixit social, esdevingui un clam i s'hi sumi la Seu del Districte. 
Pel primer curs s'han establert tres fases pels tres trimestres:

1. Contacte amb entitats, anàlisi històrica i recerca de documentació.

2. Autoaprenentatge 3D, generació del 3D colllaborativament i disseny de propostes.

3. Impressió 3D, valoració dels aprenentatges, difusió del projecte i celebració.

En les indagacions hem descobert que recentment hi ha hagut iniciatives de caràcter reivindicatiu del barri per tal d'aturar la destrucció de la masia i també en oposició a alguns usos previstos que no comptaven amb consens social. La recerca, el projecte i les accions proposades connecten amb aquestes mobilitzacions, i també continuaran les reivindicacions històriques dels anys 70 i 80 per tal d'aconseguir barris més dignes.

A diferència d'iniciatives similars en la qual un centre educatiu apadrina un element i tot l'alumnat se'n beneficia educativament, aquest projecte proposa una iniciativa bottom-up en la qual l'acció ve generada per l'alumnat i s'expandirà a la comunitat, al barri i a la ciutat.

L'alumnat ha estat reptat amb molts aprenentatges més enllà dels continguts: establir relació directa amb entitats amb llenguatge formal, compromís en les reunions i trobades, esperit crític en la interpretació de la realitat i la documentació analitzada, iniciativa i autonomia per pensar i realitzar la propera passa en el projecte, creativitat i resiliència per resistir i resoldre allò que no funciona...

La intenció és que la proposta de rehabilitació arquitectònica de la masia i els seus usos s'adeqüin amb les entitats participants, resolguin necessitats socials $\mathrm{i}$ «facin barri». La revitalització d'aquesta peça pot col-laborar en generar una Rambla Verda que travessi la Meridiana i reconnecti Nou Barris i Sant Andreu, els dos districtes de procedència de l'alumnat de l'institut.

L'avaluació educativa de l'alumnat consistirà amb qüestionaris de coavaluació i entrevistes per evidenciar si la recerca, la implicació, les exposicions, el producte, el procés i el vincle amb les entitats els han transformat en ciutadans actius, crítics, compromesos, resilients i optimistes!

L'avaluació del procés tindrà en compte que el projecte hagi estat capaç d'alinear-se amb les iniciatives prèvies i esdevenir una baula més per transformar Can Valent en un equipament patrimonial protegit amb un ús cívic consensuat. En el cas que s'aconsegueixi un compromís ferm a rehabilitar l'edifici, el projecte entraria en una nova dimensió educativa en què l'alumnat participaria activament en la direcció del projecte i en l'execució de les obres. El temps dirà.

\section{Conclusions}

En els casos exposats podem reconèixer que l'arquitectura hi és present però que en comptes d'aparèixer de manera directa, central i acaparant l'espai dels continguts conceptuals, realitza aportacions des d'un espai d'acompanyament, com a vector de transmissió.

L'arquitectura s'insinua en cada dibuix, construcció o mirada, per expressar maneres de veure i entendre el món, amb un impuls inherent per millorar-lo, amb un desig de posar en relació allò que aparentment no la té, i des d'unes capacitacions multidisciplinàries que transcendeixen l'art i la ciència. 
Els Dibuixos Construïts són activitats disruptives per l'alumnat perquè es relacionen en oposició a alguns principis evolutius naturals com els de la Importància de la Mida, el de l'Imperatiu Territorial i el dels Raigs X (Marín, 1988; Pineda, 2017). Precisament quan aquest conflicte cognitiu es resol des d'un treball conscient, es generen transformacions profundes que milloren les capacitats dels alumnes i desenvolupen les nocions de l'espai i de la profunditat.

Complementàriament al desenvolupament perceptiu de l'espai, en les Construccions amb Lego es busca el desenvolupament de les capacitats per resoldre la figura i la forma, en aquest cas per vies manipulatives. Amb aquesta activitat de construcció es genera una associació entre la representació i la figura, i en paral.lel al pensament tridimensional es millora el pensament ortogonal abstracte.

El treball de la maqueta de Sant Climent de Taüll està pensat per desenvolupar a un nivell superior de maduració el pensament tridimensional, gràcies a la descomposició de la tridimensionalitat en plans (de dues dimensions). En aquest procés es reconeixen contextualitzadament alguns conceptes del dièdric que permeten millorar substancialment les destreses gràfiques en dibuix tècnic.

El treball amb maquetes permet que des d'aproximacions arquitectòniques s'explorin les relacions entre la geometria i les matemàtiques. Aquestes connexions horitzontals col-laboren en l'adquisició i el desenvolupament de les intel-ligències Espacial i LògicaMatemàtica (Gardner, 1983, 2012, 2013)

El Dibuix en Perspectiva genera una capacitació inherent en el dibuix, ja que desenvolupa la versatilitat i la pràctica en el dibuix a mà alçada, per millorar els resultats a l'hora d'assajar, pensar i construir mentalment figures i representacions que són prèviament imaginades. De nou es colllabora en la dissecció de l'espai per mètodes analítics (plans verticals, superfícies horitzontals, elements inclinats, llums, ombres, textures...), avançant-se per currículum a la perspectiva cònica, que si s'ensenya es fa amb molta posterioritat.

El dibuix, tradicionalment associat a l'Art però eina fonamental dels arquitectes és molt més que la representació figurativa fidedigna de la realitat, ja que desenvolupa la creativitat i el pensament divergent perquè activa l'hemisferi dret per superar la submissió racional (Edwards, 2011).

A més, ja que habitualment no s'ensenya a dibuixar (en les etapes obligatòries no especialitzades), es desprenen conclusions com que les fases genetico-constructivistes relatives al dibuix infantil no són estables en relació a edats predeterminades (Pineda, 2017) i, per tant, aquestes es poden alterar.

En el projecte Salvem Can Valent, la cultura, l'arquitectura i les arts juguen un paper preponderant però no protagonista. La masia catalana, com a element patrimonial i cultural representatiu de la vida rural al llarg de diversos segles, és objecte d'estudi necessari en el projecte, però alhora s'hi posen en relació la història llunyana del barri, les reivindicacions socials dels darrers quaranta anys, i el seu desencaix urbà en un entorn (cementiri de Sant Andreu, aparcament provisional, institut i centre comercial) de diàleg impossible pel que queda de l'antiga masia. Molts elements en relació, sustentats per l'arquitectura com a fil conductor. 
En les cinc propostes presentades, tots els coneixements, capacitats, habilitats i actituds que s'han plantejat desenvolupar i que utilitzen l'arquitectura com un mitjà per accedir-hi són, paradoxalment, allò que l'arquitectura pot aportar a la societat.

L'activitat professional per part dels arquitectes requereix del pensament tridimensional, l'ús del dibuix entès com a eina, la destresa en realitzar maquetes, creativitat, resolució de problemes complexes, pensament divergent i crític, treball en equip, sensibilitat, i altres habilitats del segle XXI.

L'arquitectura esdevé un mitjà que: permet desenvolupar les capacitats de l'alumnat, oferir-li eines d'interpretació de la realitat i del patrimoni construït i, com a finalitat plena: intervenir-hi, prendre-hi posicionament i transformar-la.

Posar-se en acció de transformar un espai, un fet arquitectònic o un repte urbanístic (Morales, 1998) ${ }^{11}$ genera també una transformació profunda i necessària en l'agent transformador, de sensibilització vers el patrimoni cultural, de desvetllament dels fils relacionals, dels sistemes de valors que projectem en l'objecte d'estudi, d'identificació dels hàbits i prejudicis, i superació de les nostres creences i limitacions (Pineda, 2016).

Invertir en arquitectura en l'educació, convertir aquesta finalitat transformadora en horitzó, permetrà una societat: sensible als espais i a com ens afecten, conscient dels usos i funcionament del joc arquitectònic, amant de la bellesa i del disseny, més entenedora i per tant molt més exigent amb l'arquitectura i els arquitectes però, sobretot, agosarada, activa, resilient i amb convicció per transformar la realitat i el nostre entorn.

\section{Referències}

Berger, R. (2011) Austin's Butterfly: Building Excellence in Student Work. Disponible a: https://vimeo.com/38247060 [accés: 30.01.2021].

Branda, L. (2009) «L'aprenentatge basat en problemes. Consideracions generals». L'Aprenentatge basat en problemes en l'educació superior. Bellaterra, IDES i Servei de Publicacions de la UAB, p. 11-46.

Carbonell, J. (2016) «Les tres primaveres pedagògiques». El diari de l'Educació (Barcelona, Fundació Periodisme Plural). Disponible a: http://diarieducacio.cat/les-tresprimaveres-pedagogiques [accés: 30.01.2021].

Cobo, C. i Moravec, J. W. (2011) Aprendizaje invisible. Hacia una nueva ecología de la educación. Barcelona, Laboratori de Mitjans Interactius

De la Cerda, M. (2016) Aliances per a l'èxit educatiu: Orientacions per desenvolupar un projecte Magnet. Barcelona, Fundació Jaume Bofill.

Delors, J. (1996) «Los cuatro pilares de la educación». La educación encierra un tesoro. Informe a la UNESCO de la Comisión internacional sobre la educación para el siglo XXI, UNESCO, p. 91-103.

Edwards, B. (2011) Nuevo aprender a dibujar con el lado derecho del cerebro. Barcelona, Urano.

(11) Montserrat Morales, en l'article «Espai arquitectònic i educació», el qual forma part del monogràfic número 19 de Temps d'Educació dedicat a «Arquitectura i Educació» (1998), posa de relleu l'escassa tradició en propostes d'intervenció reals ens els espais, les arquitectures i l'urbanisme, en el paraigües educatiu, així com les repercussions positives que se'n deriven. 
Gardner, H. (1983) Frames of Mind: The Theory of Multiple Intelligences. New York, Basic Books.

Gardner, H. (2012) La inteligencia reformulada. Las inteligencias múltiples en el siglo XXI. Barcelona, Paidós. (Obra original: Intelligence reframed: multiple intelligences for the 21st century. New York, Basic Books, 1999).

Gardner, H. (2013) Inteligencias múltiples. La teoría en la práctica. Barcelona, Paidós. (Obra original: Multiple intelligences. The Theory in practice. New York, Basic Books, 1993).

Generalitat de Catalunya [Gencat] (2007) Decret 143/2007, de 26 de juny, pel qual s'estableix l'ordenació dels ensenyaments de l'educació secundària obligatòria. Diari Oficial de la Generalitat de Catalunya (27.11.2009).

Generalitat de Catalunya [Gencat] (2008) Educació, currículum educació secundària obligatòria. Departament d'Educació, Servei de Comunicació, Difusió i Publicacions.

Generalitat de Catalunya [Gencat] (2017) Llei 12/2017, del 6 de juliol, de l'arquitectura. Diari Oficial de la Generalitat de Catalunya (13.7.2017).

Hernández, F. (2000) «Los proyectos de trabajo: la necesidad de nuevas competencias para nuevas formas de racionalidad». Educar, núm. 26 (Educación y desarrollo de competencias), p. 39-51.

Hernández-Hernández, F., Alabat, I., Álvarez, C., Anguita, M., López, J., Prat, S., Segarra, M.,... Domi Viñas, D. (2016) «La moda de los proyectos». Cuadernos de pedagogía, núm. 467, p. 80-85.

Laaksonen, E. i Räsänen, J. (Ed.) (2006) Playce: Architecture Education for Children and Young People. Helsinki, Alvar Alto Academy.

Lowenfeld, V. (1961) Desarrollo de la capacidad creadora. Buenos Aires, Kapelusz.

Marín, R. (1988) «El dibujo infantil: tendencias y problemas en la investigación plástica de los escolares». Arte, Individuo y Sociedad (Universidad Complutense, Servicio de Publicaciones), núm. 1, p. 5-30.

Martín, X. (2011) «Treball per projectes amb servei a la comunitat». Temps d'Educació, núm. 41, p. 57-67.

Morales, M. (1998) «Espai arquitectònic i educació». Temps d'Educació, núm. 19, p. 35-48.

Muntañola, J. (1973) La arquitectura como lugar. Barcelona, Edicions UPC.

Muntañola, J. (1984) El niño y la arquitectura. Manual introductorio sobre la enseñanza de la arquitectura y del urbanismo en las escuelas. Barcelona, Oikos-Tau.

OECD (2010) The Nature of Learning: Using Research to Inspire Practice. Dumont, H., Istance, D., Benavides, F. [ed.] París, OECD Publishing.

Palos, J. (2011) «Aprenentatge servei. Aprendre de forma competencial i amb responsabilitat social». Temps d'Educació, núm. 41, p. 25-40.

Pineda, R. (2016) «Primary Students' Empowerment Through Critical Thinking: A Study Case To Transform Their School». A European Conference of Educational Research, ECER2016, Network3: Curriculum Innovation - 03 SES 12: 21st Century Skills and the Curriculum. European Educational Research Association, EERA, Dublin.

Pineda, R. (2017) El procés d'adquisició de la noció de VOLUM. Una recerca basada en la pràctica sobre les capacitats espacials $i$ el pensament tridimensional, per al seu desenvolupament a l'Educació Primària. Barcelona, Universitat de Barcelona (tesi doctoral; director: Fernando Hernández). 
Pineda, R., Callís i Franco, J. i Callís i Figueres, J. (2018) «Educación arquitectónica para la formación crítica». Investigación en la Escuela, núm. 94, p. 1-15. Disponible a: https://doi.org/10.12795/IE.2018.i94.01 [accés: 30.01.2021].

Romañá, T. (2015) «Educación y arquitectura: un monográfico para un campo emergente». Bordón. Revista de Pedagogía (Sociedad Española de Pedagogía), núm. 68 (1), p. 27-39.

Schabmann, A., Popper, V., Schmidt, B. M., Kühn, C., Pitro, U. i Spiel, C. (2016) «The relevance of innovative school architecture for school principals». School Leadership and Management (UK, Taylor \& Francis), 36 (2), p. 184-203.

UNESCO (2017) Educació per als Objectius de Desenvolupament Sostenible: Objectius d'aprenentatge. Barcelona, Centre UNESCO de Catalunya.

Vygotsky, L. S. (1996) El desarrollo de los procesos psicológicos superiores. Barcelona, Crítica. 


\section{La arquitectura en la educación obligatoria, medio o fin?}

Resumen: Al amparo de la nueva Ley de Arquitectura -por la que se reafirma la necesidad de que ésta se enseñe en la educación obligatoria- y en el cruce de la primavera de renovación pedagógica -que sacude las finalidades y los métodos que hegemónicamente han existido en las aulas-, este artículo aborda la disyuntiva que la arquitectura se instaure como un fin en sí misma o como un medio para acceder a otros escenarios educativos. A partir de una revisión de varias experiencias, se exploran alternativas en cuanto a los fines de los conocimientos de la arquitectura, del patrimonio arquitectónico y de la profesión de arquitecto. Asimismo, se explora la inclusión de la arquitectura en los currículos como nuevas oportunidades para revisar las metodologías educativas y los procesos de enseñanza-aprendizaje.

Palabras clave: Educación, arquitectura, capacitación, interpretación, transformación, dibujo, maqueta, arquiescola.

\section{L'architecture dans l'enseignement obligatoire : un moyen ou une finalité?}

Résumé: En vertu de la nouvelle loi sur l'architecture - qui réaffirme la nécessité d'enseigner l'architecture dans l'enseignement obligatoire - et coïncidant avec un printemps de renouveau pédagogique - qui remet en question les buts et les méthodes qui prédominaient dans les salles de classe -, cet article traite du dilemme de l'architecture conçue comme une fin en soi ou comme un moyen d'accéder à d'autres scénarios éducatifs. Sur la base d'une analyse de diverses expériences, des solutions sont étudiées en ce qui concerne les finalités des connaissances de l'architecture, du fait architectural et du métier d'architecte. En outre, l'inclusion de l'architecture dans les programmes d'études est étudiée comme une nouvelle possibilité de revisiter les méthodologies pédagogiques et les processus d'enseignement et d'apprentissage.

Mots clés: Éducation, architecture, formation, interprétation, transformation, dessin, maquette, arquiescola

\section{Architecture in compulsory education, means or purpose?}

Abstract: Under the new Law of Architecture -which reaffirms the need to be taught in compulsory education- and at the juncture of the spring of pedagogical renewal -which shakes the purposes and methods that hegemonically have existed in classrooms-, this article addresses the disjunctive that architecture is intended as an end in itself or as a medium of accessing other educational scenarios. Based on a review of various experiences, alternatives are explored the purposes of the knowledge of architecture, architectural heritage and the profession of architect. In addition, the inclusion of architecture in curricula is explored as new opportunities to review educational methodologies and teaching-learning processes.

Key words: Education, architecture, training, interpretation, transformation, drawing, model, arquiescola. 